\title{
Subject: Posterminaries - thank you for your consideration
}

Bulletin@mrs.org

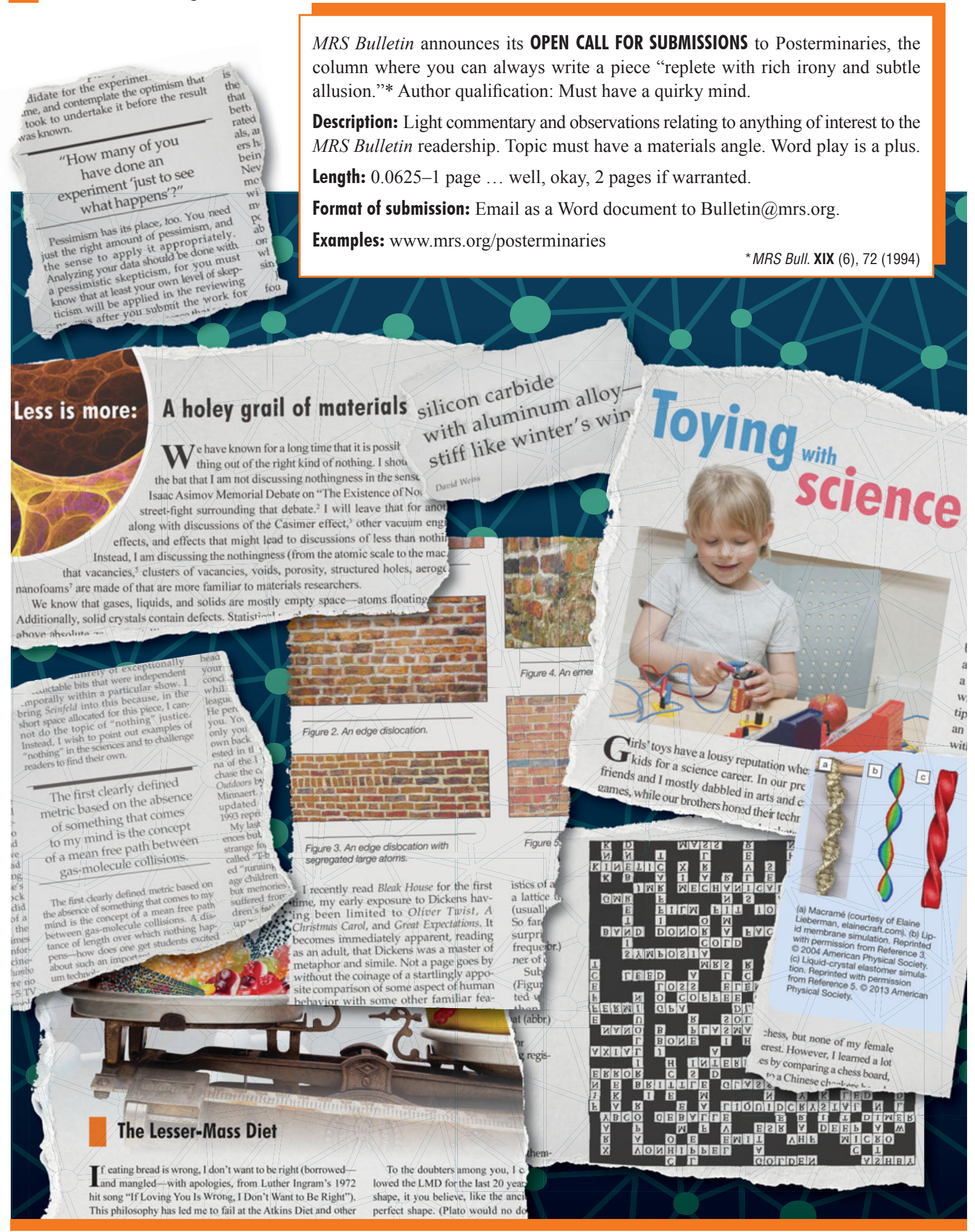

